\title{
Pengungkapan Corporate Social Responsibility dan Kinerja Keuangan Perusahaan Perbankan
}

\author{
Ni Made Widyasari ${ }^{1}$ \\ Fakultas Ekonomi dan Bisnis \\ Universitas Udayana, Indonesia
}

\author{
Ketut Yadnyana ${ }^{2}$ \\ Fakultas Ekonomi dan Bisnis \\ Universitas Udayana, Indonesia
}

\begin{abstract}
Surel : widyaasari6@gmail.com
ABSTRAK

Berkembangnya suatu perusahaan dapat mengakibatkan eksploitasi terhadap sumber alam menjadi semakin tinggi, sehingga penting bagi suatu perusahaan untuk melaksanakan aktifitas CSR. Penelitian ini bertujuan untuk mendapatkan bukti empiris dari pengujian pengaruh pengungkapan corporate social responsibility (CSR) terhadap kinerja keuangan bank yang diproksikan dengan return on asset (ROA) dan return on equity (ROE). Sampel diperoleh menggunakan metode purposive sampling sehingga diperoleh sebanyak 19 perusahaan dengan total 95 pengamatan. Teknik analisis regresi data panel digunakan untuk menganalisis data. Hasil analisis menunjukkan pengungkapan corporate social responsibility (CSR) memiliki pengaruh positif dan signifikan terhadap kinerja keuangan bank yang diproksikan dengan return on asset (ROA) dan return on equity (ROE). Implikasi dari penelitian ini dapat memberikan kontribusi dalam kajian empiris mengenai stakeholder theory dan equity theory. Implikasi dari penelitian ini yaitu dapat dijadikan bahan pertimbangan dalam pengambilan keputusan oleh para stakeholder maupun manajemen perusahaan.
\end{abstract}

Kata Kunci: Pengungkapan CSR; ROA; ROE.

\section{Disclosure of Corporate Social Responsibility and Financial Performance of Banking Companies}

\begin{abstract}
A company Development can made the ekspoitation of natural resources to be higher, so it is important for the companies to carry out CSR activities. This study aims to determine the effect of corporate social responsibility disclosure on financial performance in Bank sector as proxied by eeturn on assets (ROA) and return on equity (ROE). The sample was obtained using purposive sampling method and the number of research samples was 19 companies with a total of 95 observations. The data analysis technique in this study was panel data regression analysis. The results show that corporate social responsibility (CSR) disclosure has a positive and significant effect on financial performance in bank sector as proxied by return on assets (ROA) and return on equity (ROE). The implication of this research can contribute to the empirical study of stakeholder theory and equity theory. The implication of this research is that it can be taken into consideration in decision making by stakeholders and company management.
\end{abstract}

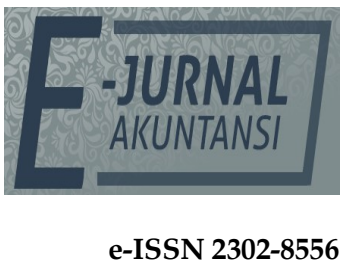

Vol. 31 No. 7

Denpasar, Juli 2021 Hal. 1655-1666

10.24843/EJA.2021.v31.i07.p04

PENGUTIPAN:

Widyasari, N.M., \& Yadnyana, K. (2021). Pengungkapan Corporate Social Responsibility dan Kinerja Keuangan

Perusahaan Perbankan. EJurnal Akuntansi, 31(7), 1655-

1666

RIWAYAT ARTIKEL: Artikel Masuk: 13 Januari 2021

Artikel Diterima: 24 Maret 2021

Keywords: $\quad$ CSR Disclosure; ROA; ROE.

Artikel dapat diakses : https://ojs.unud.ac.id/index.php/Akuntansi/index 


\section{PENDAHULUAN}

Berdirinya perusahaan di suatu negara dapat berdampak positif dan negatif. Berdampak posistif karena salah satu roda penggerak perekonomian suatu negara adalah perusahaan. Namun berkembangnya perusahaan juga berdampak pada tingkat eksploitasi sumber-sumber alam dan masyarakat yang semakin tinggi (Putra \& Wirakusuma, 2017). Perusahaan tidak dapat menjalankan aktivitas operasinya sendiri, terdapat pihak eksternal yang ikut memegang peranan penting dalam operasional perusahaan yaitu masyarakat dan lingkungan (Sari et al., 2016). Untuk mencegah dampak negatif tersebut, penting bagi suatu perusahaan untuk memperhatikan stakeholder dan lingkungan disekitarnya, salah satunya dengan melaksanakan aktivitas corporate social responsibility (CSR). Menurut penelitian Ashraf et al., (2017) selain memaksimalkan laba, perusahan juga harus bertanggungjawab kepada lingkungan dan masyarakat sekitarnya. Corporate social responsibility (CSR) merupakan sebuah strategi yang digunakan perusahaan untuk mengakomodasi kebutuhan dan kepentingan stakeholdernya. Corporate social responsibility (CSR) dijadikan sebagai imbalan atas dampak kegiatan operasi perusahaan yang menyebabkan ketidaknyamanan bagi masyarakat sekitar. Selain itu CSR juga dianggap sebagai investasi sosial yang dilakukan perusahaan untuk menghasilkan keuntungan. Laporan tahunan adalah media yang digunakan perusahaan untuk mengungkapkan aktivitas CSR yang telah diterapkan. Pengungkapan CSR dapat memperbaiki citra perusahaan di depan publik dan pada akhirnya masyarakat akan tertarik untuk mempercayakan dananya kepada perusahaan tersebut (Sari et al., 2016).

Dalam ajang penghargaan Teropong CSR Awards 2020 terdapat 13 perusahaan yang dinilai memiliki kualitas penilaian pengungkapan Corporate Social Responsibility (CSR) tertinggi dan berhasil memenangkan penghargaan tersebut. Perusahaan yang dimaksud diantaranya adalah "PT Telekomunikasi Indonesia (Persero) Tbk, PT Pertamina (Persero), PT Hutama Karya (Persero), PT Telekomunikasi Seluler (Telkomsel), PT Indofood Sukses Makmur Tbk, PT Wahana Ottomitra Multiartha (WOM) Finance Tbk, PT Bank Rakyar Indonesia, PT Food Tjipinang Jaya, PT Bank Negara Indonesia (Persero) Tbk, Perumda Pasar Jaya, PT Smartfren Telecom Tbk, PT Sumber Alfaria Trijaya (Alfamart) Tbk" Berdasarkan penghargaan tersebut, terlihat bahwa dari sektor jasa perbankan hanya PT Bank Rakyat Indonesia (Persero) Tbk dan PT Bank Negara Indonesia (Persero) Tbk yang aktif mendapatkan penghargaan. Hal ini berarti masih lemahnya tingkat pengungkapan corporate social responsibility (CSR) pada sektor perbankan di Indonesia. Di Indonesia sendiri pengungkapan CSR telah diatur dalam UU No 40 Pasal 74 tahun 2007 yang menjelaskan bahwa Perusahaan yang menjalankan kegiatan usahanya dan atau berkaitan dengan sumber daya alam wajib melaksanakan CSR Selain itu OJK juga telah menetapkan Peraturan Otoritas Jasa Keuangan Nomor 51/POJK.03/2017 tentang Penerapan Keuangan Berkelanjutan bagi Lembaga Jasa Keuangan, Emiten, dan Perusahaan Publik Pengungkapan corporate social responsibility (CSR) cenderung akan mempengaruhi kinerja keuangan perusahaan melalui beberapa elemen perusahaan seperti pertimbangan dari investor (Ashraf et al., 2017).

Menurut (Sihotang et al., 2018) kinerja keuangan merupakan alat ukur yang dapat mengukur keberhasilan suatu organisasi atau perusahaan dalam 
menghasilkan laba. Kinerja keuangan menunjukan kondisi keuangan suatu perusahaan yang mencerminkan prestasi kerja dalam periode tertentu (Luthan, et al., 2017). Profitabilitas digunakan untuk mengukur kinerja keuangan dalam penelitian ini. Rasio profitabilitas yang digunakan adalah ROA dan ROE (Sudaryanti \& Riana, 2017). Return on asset (ROA) merupakan tingkat pengembalian laba atas total asset yang tertera di dalam neraca perusahaan yang menjadi ukuran kinerja manajemen tingkat atas. Return on equity (ROE) merupakan tingkat pengembalian laba atas total ekuitas pemegang saham. ROE digunakan sebgai tolak ukur seberapa besar yang akan didapatkan investor atas dana yang diinvestasikan. Hasil penelitian Suciwati et al (2016) menjelaskan bahwa pengungkapan CSR memiliki hubungan yang positif signifikan terhadap ROA dan ROE. Hasil tersebut sejalan dengan penelitian Maqbool \& Zameer (2018) yang menunjukan bahwa CSR berpengaruh positif terhadap kinerja keuangan bank India.

Stakeholder theory menyatakan bahwa perusahaan tidak terlepas dari peran stakeholders dalam aktivitas bisnisnya (Adeneye \& Ahmed 2015). Penting bagi perusahaan untuk melaksanakan pengungkapan aktivitas corporate social responsibility (CSR) guna memuaskan stakeholders. Mengungkapkan aktivitas corporate social responsibility (CSR) dalam laporan tahunan dipandang sebagai social marketing bagi perusahaan Suciwati et al (2016). Social marketing akan bermanfaat pada pembentukkan reputasi perusahaan di mata publik sehingga dapat meningkatkan volume unit produksi yang terserap pasar yang akhirnya berdampak pada peningkatan laba dan mendorong peningkatan kinerja keuangan perusahaan. Hal tersebut didukung dengan adanya equity theory yang menyatakan bahwa dengan mengungkapkan corporate social responsibility (CSR) stakeholder, masyarakat maupun lingkungan akan merasa diperlakukan adil dan puas terhadap kinerja perusahaan. Reputasi perusahaan dimata stakeholder akan meningkat tercermin dari tingginya daya beli mereka pada produk-produk perusahaan tersebut. Berdasarkan hal tersebut perusahaan akan mendapat kepercayaan dari masyarakat sehingga akan berdampak positif terhadap kinerja keuangan perusahaan. Return on asset (ROA) adalah perbandingan antara laba bersih setelah pajak dengan aktiva untuk mengukur tingkat pengembalian investasi total (Putri \& Wirajaya, 2019).

$\mathrm{H}_{1}$ : Pengungkapan Corporate Social Responsibility (CSR) berpengaruh positif terhadap kinerja keuangan bank yang diproksikan dengan Return On Asset (ROA).

Stakeholder theory mendukung adanya hubungan positif antara pengungkapan corporate social responsibility (CSR) dan kinerja keuangan. Pengungkapan sosial dianggap sebagai bagian dari dialog antara perusahaan dengan stakeholdernya (Amran et al., 2017). Memenuhi harapan implisit dari para stakeholder dan meningkatkan reputasi perusahaan di mata publik akan memberikan dampak positif pada kinerja keuangan perusahaan karena dapat menarik minat investor dan stakeholder lain (Suciwati et al.,2016). Hal tersebut didukung dengan adanya equiy theory yang menyatakan bahwa ketika seseorang merasa diperlakukan dengan adil maka hal tersebut dapat meningkatkan loyalitasnya pada perusahaan tersebut. Melalui pengungkapan corporate social responsibility (CSR), stakeholder akan merasa diperlakukan dengan adil dan 
membuat mereka merasa puas. Hal tersebut dapat meningkatkan kinerja keuangan perusahaan karena investor menjadi tertarik untuk mempercayakan modalnya pada perusahaan tersebut. ROE adalah perbandingan laba dengan equitas selama satu tahun terakhir (Putri \& Wirajaya, 2019).

$\mathrm{H}_{2}$ : Pengungkapan Corporate Social Responsibility (CSR) berpengaruh positif terhadap kinerja keuangan bank yang diproksikan dengan Return On Equity (ROE).

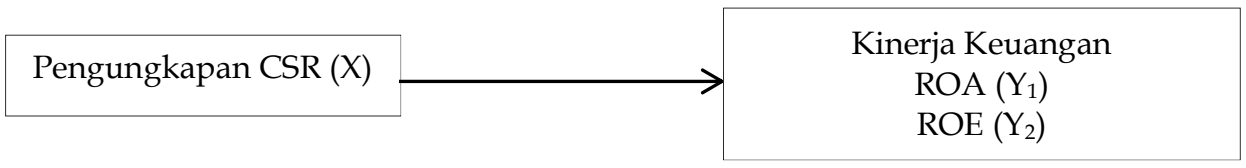

Gambar 1. Kerangka Konseptual

Sumber: Data Penelitian, 2020

\section{METODE PENELITIAN}

Dalam penelitian ini menggunakan desain penelitan asosiatif dengan pendekatan kuantitatif. Penelitian ini dilakukan pada perusahaan perbankan yang terdaftar di Bursa Efek Indonesia (BEI) periode 2015-2019. Objek penelitian dalam penelitian ini adalah kinerja keuangan bank. Populasi yang digunakan adalah seluruh perusahaan perbankan yang terdaftar di Bursa Efek Indonesia (BEI). Berdasarkan metode purposive sampling, sampel yang terpilih berjumlah 19 perusahaan dengan total 95 pengamatan. Return on asset merupakan ukuran efektifitas perusahaan di dalam menghasilkan keuntungan dengan memanfaatkan aktiva yang dimilikinya (Putri \& Wirajaya, 2019). ROA dapat diukur dengan rumus berikut.

$\mathrm{ROA}=\frac{\text { LabaUsah Setel Pajak }}{\text { Total Aset }}$

Return on equity (ROE) merupakan ukuran efektifitas perusahaan di dalam menghasilkan keuntungan dengan memanfaatkan ekuitas selama satu tahun. terakhir (Putri \& Wirajaya, 2019). Investor menggunakan ROE untuk menilai kelayakan saham yang beredar dari suatu perusahaan. ROE dapat diukur dengan rumus berikut.

$\mathrm{ROE}=\frac{\text { Laba Usa Setelah Pajak }}{\text { Ekuitas Pemegang Saham }}$

Pengukuran CSRDI dalam penelitian ini berdasarkan pada standar GRI (Global Reporting Initiative) yang terdiri dari tiga fokus pengungkapan, yaitu ekonomi, lingkungan dan sosial. Standar GRI dipilih karena lebih fokus pada standar pengungkapan kinerja ekonomi, sosial, dan lingkungan perusahaan. Menghitung CSRDI dalam penelitian ini mengacu pada GRI-G4 dengan menggunakan 91 indikator pengungkapan CSR (Sari et al., 2016). Ketika perusahaan perbankan mengungkapkan indikator, maka diberi nilai 1, jika tidak diberi nilai 0 (Ningrum et al., 2018). Rumus perhitungan CSRDI sesuai dengan penelitian (Winardi, 2012) sebagai berikut.

$\mathrm{CSRDI}_{\mathrm{j}}=\frac{\Sigma x i j}{n j}$

Keterangan : 


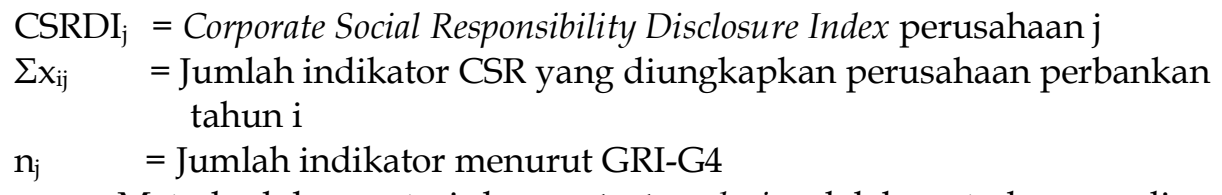

Metode dokumentasi dan content analysis adalah metode yang digunakan untuk mengumpulkan data yang kemudian dianalisis menggunakan teknik analisis regresi data panel melalui program Eviews 9. Persamaan model regresi pada penelitian ini adalah sebagai berikut.

$\mathrm{Y} 1=\alpha+\beta 1 X i t+\varepsilon i t$

$Y 2=\alpha+\beta 2 X i t+\varepsilon i t$

Keterangan:

$\mathrm{Y} 1=\mathrm{ROA}$

$\mathrm{Y} 2=\mathrm{ROE}$

$\mathrm{a}=$ Konstanta

$\beta=$ Koefisien Regresi

Xit $=$ Rasio pengungkapan CSR perusahaan i pada tahun ke-t

\section{HASIL DAN PEMBAHASAN}

Statistik deskriptif merupakan analisis yang digunakan untuk melihat nilai data minimum, maksimum, rata-rata (mean), dan deviasi standar dari masing-masing variabel penelitian. Statistik deskriptif dalam penelitian ini digunakan untuk memberikan informasi mengenai variabel-variabel penelitian yaitu pengungkan corporate social responsibility (CSR), return on asset (ROA) dan return on equity (ROE). Hail uji statistic deskriptif disajikan pada Tabel 1.

\section{Tabel 1. Hasil Statistik Deskriptif Variabel Penelitian}

\begin{tabular}{lccc}
\hline & Pengungkapan CSR & ROA & ROE \\
\hline Mean & 45,294 & 1,480 & 9,352 \\
Median & 45,000 & 1,520 & 7,820 \\
Maximum & 62,000 & 3,170 & 23,41 \\
Minimum & 30,000 & 0,090 & 0,140 \\
Std.Dev. & 6,021 & 0,859 & 6,074 \\
Skewness & 0,345 & 0,217 & 0,507 \\
Kurtosis & 3,214 & 2,025 & 2,282 \\
Jarque-Bera & 2,068 & 4,511 & 6,116 \\
Probability & 0,355 & 0,104 & 0,046 \\
Sum & 4303,000 & 140,660 & 888,460 \\
Sum Sq.Dev & 3407,747 & 69,445 & 3469,039 \\
Observation & 95 & 95 & 95 \\
\hline
\end{tabular}

Sumber: Data Penelitian, 2020

Berdasarkan Tabel 1, dapat diketahui bahwa data hasil uji statistik deskriptif yang meliputi nilai mean, nilai median, nilai minimum, nilai maksimum dan standar deviasi dari masing-masing variabel, dengan jumlah pengamatan yang berjumlah 95 pengamatan. Misalkan variabel pengungkapan CSR memiliki nilai minimum sebesar 30,000 dan nilai maksimum 62,000. Nilai rata-rata sebesar 45.29474 menunjukan bahwa pengungkapan CSR berpengaruh terhadap kinerja keuangan bank serta penyimpangan nilai rata-ratanya ditunjukan melalui angka pada standar deviasi sebesar 6,021. Begitu pula dengan variabel ROA dan ROE. 
WIDYASARI, N.M., \& YADNYANA, K.

Tingkat pengungkapan CSR perusahaan perbankan dari tahun 2015-2019 disajikan pada Gambar 2, berikut.

Pengungkapan CSR Perusahaan Perbankan

2015-2019

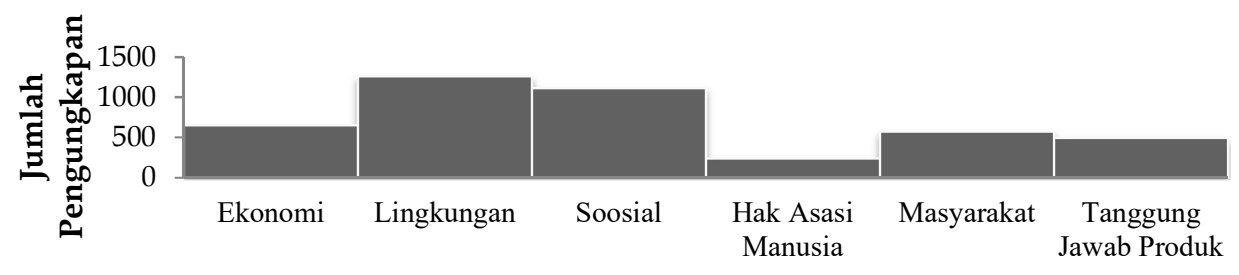

Kategori Pengungkapan

\section{Gambar 2. Tingkat Pengungkapan CSR Perusahaan Perbankan}

Sumber: Data Penelitian, 2020

Berdasarkan Gambar 2, dapat dijelaskan bahwa dari 91 item pengungkapan CSR yang terbagi kedalam 6 kategori, tingkat pengungkapan CSR yang paling tinggi terletak pada kategori lingkungan dan terendah terletak pada kategori hak asasi manusia. Hal tersebut menunjukan bahwa pengungkapan CSR yang paling sering diungkapkan perusahaan perbankan dari tahun 2015-2019 adalah item pengungkapan CSR pada kategori lingkungan. Untuk menentukan model analisis yang akan digunakan diperlukan adanya uji spesifikasi model. Untuk mmenentukan antara model fixed effect atau model common effect yang sebaiknya dipakai maka dilakukan uji chow. Hasil uji chow pengaruh pengungkapan CSR terhadap ROA disajikan pada Tabel 2.

Tabel 2. Uji Chow

\begin{tabular}{lccc}
\hline Effects Test & Statistic & d.f. & Prob. \\
\hline Cross-section F & 51,078 & $(18,75)$ & 0,000 \\
Cross-section Chi-square & 245,542 & 18 & 0,000 \\
\hline
\end{tabular}

Sumber: Data Penelitian, 2020

Berdasarkan Tabel 2, diperoleh nilai Probability Cross-Section Chi Square lebih kecil dari alpha $(0,000<0,05)$, sehingga $\mathrm{H}_{0}$ ditolak. Artinya Fixed Effect Model (FEM) lebih tepat digunakan daripada Common Effect Model (CEM). Untuk mengetahui model yang lebih tepat dugunakan diantara Fixed Effect Model (FEM) atau Random Effect Model (REM) maka dilakukan uji hausmann. Hasil uji hausmann pengaruh pengungkapan CSR terhadap ROA disajikan pada Tabel 3.

Tabel 3. Hausman Test

\begin{tabular}{llll}
\hline Test Summary & Chi-Sq. Statistic & Chi-Sq. d.f. & Prob. \\
\hline Cross-section random & 5,005 & 1 & 0,025 \\
\hline
\end{tabular}

Sumber: Data Penelitian, 2020

Tabel 3, menunjukan bahwa nilai probabilitas pada Cross-section random lebih kecil dari alpha $(0,025<0,00)$, sehingga $\mathrm{H}_{0}$ ditolak. Artinya Fixed Effect Model adalah model yang tepat digunakan. Hasil uji chow pengaruh pengungkapan corporate social responsibility (CSR) terhadap return on equity (ROE) disajikan pada Tabel 4. 
Berdasarkan Tabel 4, diperoleh nilai Probability Cross-section Chi-square lebih kecil dari alpha $(0,000<0,05)$, sehingga $\mathrm{H}_{0}$ ditolak. Artinya Fixed Effect Model (FEM) lebih tepat digunakan daripada Common Effect Model (CEM).

Tabel 4. Uji Chow

\begin{tabular}{lrrr}
\hline Effects Test & Statistic & d.f. & Prob. \\
\hline Cross-section F & 19,092 & $(18,75)$ & 0,000 \\
Cross-section Chi-square & 163,361 & 18 & 0,000 \\
\hline
\end{tabular}

Sumber: Data Penelitian, 2020

Hasil uji hausmann pengaruh pengungkapan CSR terhadap ROE disajikan pada Tabel 5, menunjukan bahwa nilai probabilitas pada Cross-section random lebih besar dari alpha $(0,108>0,05)$, sehingga $\mathrm{H}_{0}$ diterima. Artinya Random Effect Model (REM) lebih tepat digunakan daripada Fixed Effect Model (FEM). Hasil pengujian belum menemukan persamaan metode, maka dilanjutkan dengan metode penentu yaitu uji langrange multiplier.

Tabel 5. Hausman Test

\begin{tabular}{lrrr}
\hline Test Summary & Chi-Sq. Statistic & Chi-Sq. d.f. & Prob. \\
\hline Cross-section random & 2,577 & 1 & 0,108 \\
\hline
\end{tabular}

Sumber: Data Penelitian, 2020

Hasil uji langrange multiplier disajikan pada Tabel 6, Uji langrange multiplier bertujuan untuk menentukan model yang lebih tepat digunakan diantara Common Effect Model (CEM) dan Fixed Effect Model (FEM). Tabel 6, menunjukan bahwa nilai Cross-Section Breusch-Pagan lebih kecil dari alpha $(0,000<0,05)$, sehingga $\mathrm{H}_{0}$ ditolak. Artinya Random Effect Model (REM) adalah model yang tepat untuk digunakan.

Tabel 6. Uji Langrange Multiplier

\begin{tabular}{llll}
\hline & Test Hypothesis & & \\
& Cross-section & Time & Both \\
\hline Breusch-Pagan & 106,253 & 0,055 & 106,309 \\
& $(0,000)$ & $(0,813)$ & $(0,000)$ \\
\hline
\end{tabular}

Sumber: Data Penelitian, 2020

Uji asumsi klasik yang dilakukan terdiri dari uji normalitas, uji uji heteroskedastisitas dan uji autokolenearitas. Hasil uji asumsi klasik disajikan pada Tabel 7.

Tabel 7. Hasil Uji Asumsi Klasik

\begin{tabular}{lrrrr}
\hline \multicolumn{1}{c}{ Keterangan } & Normalitas & Heteroskedastisitas & Autokolenearitas \\
\hline $\begin{array}{l}\text { Pengungkapan } \\
\text { terhadap ROA }\end{array}$ & CSR & 0,199 & 0,781 & 1,886 \\
$\begin{array}{l}\text { Pengungkapan } \\
\text { terhadap ROE }\end{array}$ & CSR & 0,281 & 0,387 & 1,893 \\
\hline
\end{tabular}

Sumber: Data Penelitian, 2020

Berdasarkan Tabel 7, dapat disimpulkan bahwa tidak terjadi masalah asumsi klasik pada penelitian ini. Nilai Probability Jarque-Bera $>0,05$ menunjukan bahwa seluruh data telah berdistribusi normal. Hasil uji heteroskedastisitas menunjukan nilai probability $>0,05$ yang berarti tidak terdapat masalah heteroskedastisitas pada model. Hasil uji autokorelasi berada pada posisi tidak ditolak karena menunjukan nilai DW diantara $\mathrm{du}<\mathrm{d}<4$-du. Berdasarkan Hasil analisis regresi data panel (FEM) disajikan pada Tabel 8. 
WIDYASARI, N.M., \& YADNYANA, K.

Tabel 8. Hasil Analisis Regresi Data Panel (FEM)

\begin{tabular}{lrlrc}
\multicolumn{1}{c}{ Variable } & Coefficient & Std. Error & t-Statistic & Prob. \\
\hline C & $-2,868$ & 0,459 & $-6,240$ & 0,000 \\
$X_{1}$ & 8,737 & 0,921 & 9,478 & 0,000 \\
\multicolumn{4}{c}{ Effects Specification } & \\
Cross-section fixed (dummy variables) & & \\
R-squared & 0,927 & Mean dependent var & 1,480 \\
Adjusted R-squared & 0,909 & S.D. dependent var & 0,859 \\
S.E. of regression & 0,258 & Akaike info criterion & 0,316 \\
Sum squared resid & 5,009 & Schwarz criterion \\
Log likelihood & 4,974 & Hannan-Quinn criter. & 0,853 \\
F-statistic & 50,777 & Durbin-Watson stat & 0,533 \\
Prob(F-statistic) & 0,000 & & 1,886 \\
\end{tabular}

Sumber: Data Penelitian, 2020

Berdasarkan pada analisis koefisien regresi pada Tabel 8, dapat dibuat persamaan regresi sebagai berikut.

$$
Y 1=-2,868+8,737 X_{1}+\varepsilon_{i t}
$$

Interpretasi dari persamaan regresi pada Tabel 8 , menunjukan nilai konstanta sebesar -2,868 menunjukkan apabila semua variabel bebas sama dengan nol, maka nilai return on asset (ROA) akan menurunkan sebesar 2,868 satuan. Nilai koefisien regresi $\mathrm{X}_{1}$ sebesar 8,737 menunjukkan jika pengungkapan corporate social responsibility (CSR) naik satu satuan, maka return on asset (ROA) akan meningkat sebesar 8.737 satuan dengan asumsi variabel lain konstan.

Berdasarkan Tabel 8, nilai Probability F-statistic lebih kecil daripada alpha $(0,000<0,05)$. Hasil tersebut menunjukan bahwa model persamaan dalam penelitian ini layak digunakan dan secara simultan berpengaruh signifikan pada kinerja keuangan yang diproksikan dengan ROA. Hipotesis pertama menyatakan bahwa pengungkapan corporate social responsibility (CSR) berpengaruh positif dan signifikan terhadap kinerja keuangan bank yang diproksikan dengan ROA. Berdasarkan Tabel 8, nilai probability t-statistic variabel pengungkapan corporate social responsibility (CSR) $0,000<0,05$. Hal tersebut menunjukan bahwa hipotesis pertama penelitian diterima, hasil sejalan dengan penelitian Suciwati et al. (2016) serta Maqbool \& Zameer (2018) yang menunjukan bahwa terdapat hubungan positif dan signifikan diantara pengungkapan CSR dan ROA.

Nilai koefisien determinasi dalam penelitian ini dapat dilihat dari nilai adjusted $R^{2}$. Berdasakan Tabel 8 , nilai adjusted $R^{2}$ pada pengujian pengaruh pengungkapan corporate social responsibility (CSR) terhadap return on asset (ROA) menunjukan nilai sebesar 0,909. Hal ini menandakan 90,9 persen dari variansi return on asset (ROA) perusahaan perbankan yang terdaftar di Bursa Efek Indonesia (BEI) tahun 2015-2019 dijelaskan oleh variabel pengungkapan corporate social responsibility (CSR) sedangkan sisanya sebesar 10 persen dipengaruhi oleh faktor-faktor lain yang tidak dimasukkan dalam model regresi. Hasil analisis regresi data panel (FEM) disajikan pada Tabel 9. 
Tabel 9. Hasil Analisis Regresi Data Panel (REM)

\begin{tabular}{rrrrr}
\hline \multicolumn{1}{c}{ Variable } & Coefficient & Std. Error & t-Statistic & Prob. \\
\hline C & $-1,059$ & 0,337 & $-3,139$ & 0,002 \\
$\mathrm{X}_{1}$ & 32,888 & 8,449 & 3,892 & 0,000 \\
& Effects Specification & & Rho \\
Cross-section random & & S.D. & 0,000 \\
Idiosyncratic random & & 0,000 & 1,000 \\
& & & 2,932 & \\
R-squared & Weighted Statistics & & $-1,158$ \\
Adjusted R-squared & 0,186 & Mean dependent var & 3,054 \\
S.E. of regression & 0,175 & S.D. dependent var & 569,319 \\
F-statistic & 2,773 & Sum squared resid & 1,893 \\
Prob(F-statistic) & 16,930 & Durbin-Watson stat & 0,000 \\
\hline
\end{tabular}

Sumber: Data Penelitian, 2020

Berdasarkan pada analisis koefisien regresi pada Tabel 9, dapat dibuat persamaan regresi sebagai berikut.

$$
\mathrm{Y} 2=-1,059+32,888 \mathrm{X}_{1}+\text { cit }
$$

Interpretasi dari persamaan regresi pada Tabel 9, menunjukan nilai konstanta sebesar -1.059 menunjukkan apabila semua variabel bebas sama dengan nol, maka nilai return on equity (ROE) akan menurun sebesar 1.059 satuan. Nilai koefisien regresi $\mathrm{X}_{1}$ sebesar 32.888 menunjukkan jika pengungkapan corporate social responsibility (CSR) naik satu satuan, maka return on equity (ROE) akan meningkat sebesar 32.888 satuan dengan asumsi variabel lain konstan.

Berdasarkan Tabel 9, nilai Probability F-statistic lebih kecil daripada alpha $(0,000<0,05)$. Hasil tersebut menunjukan bahwa model persamaan dalam penelitian ini layak untuk digunakan dan secara simultan berpengaruh signifikan pada kinerja keuangan bank yang diproksikan dengan ROE. Hipotesis kedua menyatakan bahwa pengungkapan corporate social responsibility (CSR) berpengaruh positif dan signifikan terhadap kinerja keuangan yang diproksikan dengan ROE. Berdasarkan Tabel 9, nilai probability t-statistic variabel pengungkapan corporate social responsibility (CSR) 0,000 < 0,05. Hal tersebut menunjukan hipotesis kedua diterima, sejalan dengan penelitian Suciwati et al (2016) serta Maqbool \& Zameer (2018) yang menunjukan bahwa pengungkapan CSR berpengaruh positif dan signifikan terhadap ROE.

Berdasakan Tabel 9, nilai adjusted $R^{2}$ pada pengujian pengaruh pengungkapan corporate social responsibility (CSR) terhadap return on equity (ROE) menunjukan nilai sebesar 0,175 . Hal ini menandakan 17,5 persen dari variansi return on equity (ROE) perusahaan perbankan yang terdaftar di BEI tahun 20152019 dijelaskan oleh variabel pengungkapan corporate social responsibility (CSR) sedangkan sisanya sebesar 82,5 persen dipengaruhi oleh faktor lain yang ditak dimasukkan dalam model regresi.

\section{SIMPULAN}

Simpulan yang dapat ditarik berdasarkan hasil dan pembahasan yang sudah dijelaskan sebelumnya yaitu pengungkapan corporate social responsibility (CSR) 
berpengaruh positif dan signifikan terhadap kinerja keuangan bank yang diproksikan dengan return on asset (ROA). Artinya peningkatan pengungkapan corporate social responsibility (CSR) perusahaan perbankan berpengaruh signifikan pada peningkatan return on asset (ROA) yang didapat perusahaan perbankan tersebut. Pengungkapan corporate social responsibility (CSR) berpengaruh positif dan signifikan terhadap kinerja keuangan bank yang diproksikan dengan return on equity (ROE). Artinya peningkatan pengungkapan corporate social responsibility (CSR) perusahaan perbankan berpengaruh signifikan pada peningkatan return on equity (ROE) yang didapat perusahaan perbankan tersebut.

Penelitian ini memiliki beberapa keterbatasan diantaranya pada penilaian pengungkapan corporate social responsibility (CSR) yang masih bersifat subjektif, penelitian ini hanya berfokus pada perusahaan sektor perbankan dan periode penelitian yaitu 5 tahun. Penelitian selanjutnya disarankan untuk menggunakan keyword yang lebih tepat dalam menilai pengungkapan corporate social responsibility (CSR) pada laporan tahunan perusahaan. Penelitian selanjutnya dapat memperluas populasi penelitian dengan menggunakan seluruh perusahaan yang terdaftar di Bursa Efek Indonesia (BEI) Penelitian selanjutnya disarankan untuk memperpanjang periode penelitian untuk mendapatkan hasil yang lebih baik.

\section{REFERENSI}

Adeneye, Y., \&Ahmed, M. (2015). Corporate Social Responsibility and Companiy Performance. Journal of Business Studies Quarterly, 7(1), 151.

Alemu Kesto , Dakito. (2017). The Impact of Corporate Social Responsibility Practices On Financial Performance Of Banking Sector In Ethiopia. Global Journal Of Management And Business Research, 17(1).

Amran, A., Fauzi, H., Purwanto, Y., Darus, F., Yusoff, H., Zain, M. M., Naim, D. M. A., \& Nejati, M. (2017). Social responsibility disclosure in Islamic banks: a comparative study of Indonesia and Malaysia. Journal of Financial Reporting and Accounting. https://doi.org/10.1108/JFRA-01-2015-0016.

Ashraf, M., Khan, B., \& Tariq, R. (2017). Corporate Social Responsibility Impact on

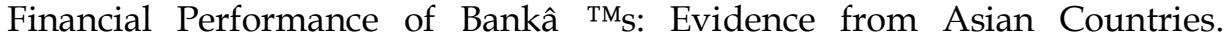
International Journal of Academic Research in Business and Social Sciences, 7(4), 618-632. https:// doi.org/10.6007/ijarbss/v7-i4/2837.

Asmeri, R,., Alvionita, T., \& Gunardi, A. (2017). CSR Disclosure In The Mining Industry: Empirical Evidence From Listed Mining Firms In Indonesia. Indonesian Journal of Sustainability Accounting and Management, 1(1), pp.16. https://doi.org/10.28992/ijsam.v1i1.23.

Bagh, T., Khan, M. A., Azad, T., \& Atif Khan, M. (2017). The Corporate Social sponsibility and Firms' Financial Performance: Evidence from Financial Sector of Pakistan. International Journal of Economics and Financial Issues, 7(2), pp.301-308. http:www.econjournals.com

Chan, T. J., \& Mohd Hasan, N. A. (2016). Determinants Of Corporate Social Responsibility (CSR) And Intrinsic Job Motivation: A Case Of Malaysian Banking Company. Malaysian Journal of Social Sciences and Humanities (MJSSH), $1(3)$, https://msocialsciences.com/index.php/mjssh/article/view/18 pp.66-82. 
Damanik, B. A., \& Yadnyana, I. K. (2017). Pengaruh Kinerja Lingkungan Pada Kinerja Keuangan Dengan Pengungkapan Corporate Social Responsibility Sebagai Variabel Intervening. E-Jurnal Akuntansi Universitas Udayana, 20(1), hal.645-673.

Hirigoyen, G., \& Poulain, T. (2015). Relationship Between Corporate Social Responsibility And Financial Performance: What Is The Causality? Journal of Business and Management, 4(1), pp.18-43. https://doi.org/10.12735/jbm.v4i1p18.

Jie, C.T., Hasan, N.A.M. (2016), Determinants of Corporate Social Responsibility (CSR) And Intrinsic Job Motivation: A Case Of Malaysian Banking Company. Malaysian Journal of Social Sciences and Humanities, 1(2), 25-35.

Kiran, S., kakakhel, S.J., \& Shaheen, F. (2015). Corporate Social Responsibility and Firm Profitability: A Case Of Oil and Gas Sector Of Pakistan. City University Research Journal, 5(1), pp.110-119.

Luthan, E.-, Rizki, S. A., \& Edmawati, S. D. (2017). Pengaruh Pengungkapan Tanggung Jawab Sosial Perusahaan Terhadap Kinerja Keuangan. EKUITAS (Jurnal Ekonomi Dan Keuangan), 1(2), 204. https://doi.org/10.24034/j25485024.y2017.v1.i2.2754.

Matuszak, Ł., \& Różańska, E. (2017). An Examination Of The Relationship Between CSR Disclosure And Financial Performance: The Case Of Polish Banks. Journal of Accounting and Management Information Systems, 16(4), pp. 522-533. https://doi.org/10.24818/jamis.2017.04005.

Maqbool, S., \& Zameer, M. N. (2018). Corporate Social Responsibility and Financial Performance: An Empirical Analysis Of Indian Banks. Future Business Journal, 4(1), 84-93. https://doi.org/10.1016/j.fbj.2017.12.002

Ngoc, N. B. (2018). The Effect of Corporate Social Responsibility Disclosure on Financial Performance: Evidence from Credit Institutions in Vietnam. Journal Of Asian Social Science, 14(4), pp.109. https://doi.org/10.5539/ass.v14n4p109.

Platnova, E., Asutay, M., Dixon, R., \&Mohammad, S. (2018). The Impact Of Corporate Social Responsibility Disclosure on Financial Performance : Evidence from the GCC Islamic Banking Sector. Journal of Bussiness Ethics, 151(2), pp. 451-471. https://doi.org/10.1007/s10551-016-3229-0.

Pratiwi, M. (2015). Penilaian Kinerja Keuangan Perusahaan Dengan Analisis Rasio Keuangan Dan Metode Economic Value Added (EVA) (Studi pada PT. Berlina, Tbk dan Anak Perusahaan yang Terdaftar di Bursa Efek Indonesia Periode 2010-2012). Jurnal Administrasi Bisnis S1 Universitas Brawijaya, vol.9(2).

Putra, A. G. T. D., \& Wirakusuma, M. G. (2017). Pengaruh Corporate Social Responsibility Disclosure Terhadap Harga Saham. E-Jurnal Akuntansi Universitas Udayana, 19, 1719-1746. https://ojs.unud.ac.id/index.php/Akuntansi/article/view/22432

Putri, P. C. T., \& Wirajaya, I. G. A. (2019). Implementasi CSR dan Dampaknya Terhadap Kinerja Keuangan. E-Jurnal Akuntansi. https://doi.org/10.24843/eja.2019.v28.i01.p16.

Sabatini, K., \& Sudana, I. P. (2019). Pengaruh Pengungkapan Corporate Social Responsibility Pada Nilai Perusahaan Dengan Manajemen Laba Sebagai Variabel Moderasi. Jurnal Ilmiah Akuntansi Dan Bisnis, 14(1). hal.59-69. 
https://doi.org/10.24843/jiab.2019.v14.i01.p06.

Sari, W. A., Handayani, S. R., \& Nuzula, N. F. (2016). Pengaruh Pengungkapan Corporate Social Responsibility Terhadap Kinerja Keuangan Dan Nilai Perusahaan ( Studi Komparatif pada Perusahaan Multinasional yang Terdaftar di Bursa Efek Indonesia dan Bursa Malaysia Tahun 2012-2015 ). Jurnal Administrasi Bisnis (JAB).

Sihotang, E., Raya, U. P., Wibowo, A. S., Raya, U. P., Angela, L. M., \& Raya, U. P. (2018). Analisis Prngaruh Kinerja Keuanganterhadap Nilai Perusahaan Dengan Pengungkapan Corporate Social Responsibilty ( Csr ) Sebagai Variabel Moderating. ResearchGate, September. https://doi.org/10.13140/RG.2.2.18029.84969.

Suciwati, D., Pradnyan, D., \& Ardina, C. (2016). Pengaruh Corporate Social Responsibility Terhadap Kinerja Keuangan (Pada Perusahaan Sektor Pertambangan di BEI Tahun 2010-2013). Jurnal Bisnis Dan Kewirausahaan, 12(2), 104-113.

Sudaryanti, D., \& Riana, Y. (2017). Pengaruh Pengungkapan CSR terhadap Kinerja Keuangan Perusahaan. Jurnal MIPA, 2(1), 19-31. https://doi.org/10.35799/jm.2.2.2013.3623.

Yusoff, W. F. W., \& Adamu, M. S. (2016) The Relationship Between Corporate Social Responsibility And Financial Performance: Evidence from Malaysia. In International Business Management, $10 \quad$ (4), pp. 345-351. https://doi.org/10.3923/ibm.2016.345.351. 